\title{
Trwałość dawnych elementów krajobrazu i sieci drożnej w ramach współczesnej przestrzeni miejskiej na przykładzie ulic Krańcowej i Wilczej w Lublinie
}

\section{Jacek Chachaj}

Szybki rozwój terytorialny miast w XIX i XX w. doprowadził do wchłonięcia przez nie okolicznych terenów, przede wszystkim wsi i osad podmiejskich. Zagospodarowanie terenów przyłączonych, związane z reguły z poważną reorganizacją ich przestrzeni, którą podporządkowywano potrzebom i interesom rozrastającego się miasta, prowadziło najczęściej do zupełnego zatarcia elementów wcześniejszego krajobrazu, w tym także śladów pierwotnych form osadniczych oraz istniejącej na terenach włączonych starszej sieci drożnej. Jedynie wyjątkowo przetrwały jej elementy, najczęściej, jeśli dotyczyło to tej części dróg, które miały ważniejsze znaczenie w komunikacji z innymi ośrodkami (rolę taką pełniły przede wszystkim dawne drogi wylotowe). Znacznie mniejsze szanse na przetrwanie $\mathrm{w}$ ramach procesu reorganizacji przestrzeni miały drogi, które pełniły funkcje połączeń lokalnych albo zostały zastąpione przez nowo wyznaczone w XIX lub XX w. trakty drożne.

W niektórych przypadkach doszło jednak do zachowania elementów dawnej sieci drożnej, która jest możliwa do odczytania w postaci niespodziewanego przebiegu niektórych ulic lub tylko ich fragmentów. $Z$ reguły ulice te zwracają uwagę swoim przebiegiem, przynajmniej częściowo niezgodnym $\mathrm{z}$ istniejącą w najbliższej okolicy siecią innych ulic oraz z układem najbliższych działek własnościowych. Często biegną ukośnie w stosunku do

\footnotetext{
1 J. Marczuk, Rada Miejska i Magistrat Lublina 1918-1939, Lublin 1984, s. 14; M. Markowski, Rozwój przestrzenny Lublina w XX wieku, „Rocznik Lubelski”, 38, 2012, s. 25.

2 Do ostatnich lat linia ta była bardzo tatwa do rekonstrukcji w terenie, choć przez wiele lat na odcinku od ulicy Długiej do Czerniejówki Krańcowa praktycznie nie istniała, będąc na przeważającej części tego odcinka jedynie ścieżką. Dopiero przeprowadzona w latach
}

innych ulic, czasem wielokrotnie zmieniają kierunek lub urywają się niespodziewanie, sprawiając wrażenie dróg, które biegną donikąd. Wydaje się, że warto przyjrzeć się przykładom tego typu „żywych pomników przeszłości geograficznej", zarówno zastanawiając się nad tym dlaczego przetrwały zmiany dotyczącej ich przestrzeni, jak też próbując odpowiedzieć na pytanie o rolę, jaką mogły odgrywać w okresie poprzedzającym przyłączenie terenu, przez który biegną do rozrastającego się ośrodka miejskiego.

Aż do drugiej dekady XX w. miasto Lublin nie sięgało $\mathrm{w}$ rejon opisywanych $\mathrm{w}$ niniejszym tekście ulic. Dopiero po dokonanym w 1916 r. rozszerzeniu zasięgu miasta między innymi o Kośminek i Bronowice ${ }^{1}$ południowa granica Lublina znacznie się przesunęła. Biegła odtąd wzdłuż późniejszej ulicy Wyścigowej, a następnie od miejsca, gdzie Wyścigowa łączyła się z ulicą Bychawską (dzisiaj Władysława Kunickiego), łamaną linią, pokrywającą się w znacznym stopniu z późniejszym przebiegiem ulicy Krańcoweje ${ }^{2}$, w przybliżeniu aż do miejsca, gdzie dzisiaj ulica ta, biegnąc w górę od ulicy Długiej, skręca ukośnie w lewo, przybierając kierunek prostopadły do Drogi Męczenników Majdanka. W tym miejscu granica miasta przybierała kierunek prawie dokładnie wschodni, choć można mieć pewne wątpliwości, czy plany Lublina z drugiej i trzeciej dekady XX w. są precyzyjne w przedstawieniu granicy miasta na interesującym nas odcinku3

2009-2010 budowa ulicy Dywizjonu 303 doprowadziła do ostatecznego zatarcia na pewnych odcinkach wcześniejszego przebiegu ulicy Krańcowej.

3 Ówczesny zasięg miasta przedstawiają plany z 1916 i 1920 r.: Plany i widoki Lublina XVII-XXI wiek, red. M. Harasimiuk, D. Kociuba, P. Dymmel, Lublin 2007, Plansza XIII: Plan M. [iasta] Lublina. 1916, litografia A. Jarzyński; J. Marczuk, Rada Miejska, Fot. 36: Plan mia- 
Możemy się spodziewać, że obrzeżem Lublina od 1916 r. była dawna granica między wsiami Bronowice i Dziesiąta, która musiała ukształtować się już w średniowieczu ${ }^{4}$.

W 1931 r. włączono do Lublina obszar rozparcelowanego majątku Dziesiąta, tym samym znacznie rozszerzając jego zasięg w kierunku południowym5. Także w 1931 r. plan Lublina przedstawia po raz pierwszy nieco inaczej przebieg granicy miasta na wschód od Czerniejówki. Na planie prowadzi ona po linii pokrywającej się z ulicą Wilczą, biegnącą nieco dalej na południe od wyraźnie widocznej ulicy Krańcowej. Sama ulica Wilcza zaznaczona jest na zachodnim odcinku tej granicy, między Długą a Robotniczą ${ }^{6}$. $\mathrm{Na}$ uproszczonym planie miasta z 1938 r. pojawia się na tym odcinku po raz pierwszy także nazwa ulicy Wilczej, a na odcinku między Bychawską a rzeką Czerniejówką oraz między Czerniejówką a Fabryczną (czyli dzisiejszą Drogą Męczenników Majdanka) nazwa ulicy Krańcowej, która kończyła się zbiegiem z ulicą Pawią na okraghym Placu Lwowskim?

Nieco dokładniejszy, w porównaniu z poprzednim, niemiecki plan z około 1940 r. wskazuje, że Wilcza biegła równolegle do wyraźnie zaznaczonych granic pól wsi Dziesiąta ${ }^{8}$. Można zatem przypuszczać, że powstanie tej drogi wią-

sta Lublina z 1920 r. Trudno powiedzieć na ile są one precyzyjne (plan z 1916 r. bez wątpienia został oparty na rosyjskim planie z lat 1912-1914: Plany i widoki Lublina, Plansza XII: Plan prigrodskich miestnostiej priedlagajemych $k$ prisojdnieniu $k$ gorodu Liublinu, M. Stelmasiewicz, K. Tomorowicz, 1912-1914), ale analiza ich treści wskazuje, że granica miasta biegła nieco na północ od dzisiejszej ulicy Wilczej. Natomiast, sprawiający wrażenie bardzo uproszczonego, plan A. Z. Krzyżewskiego z 1926 r. przedstawia przebieg granicy Lublina w taki sposób, że należałoby uznać, iż na wschód od ulicy Długiej już wówczas miasto sięgatoby do dzisiejszej ulicy Wilczej: Plany i widoki Lublina, Plansza XV: Plan Lublina, A. Z. Krzyżewski, 1926.

4 Jan Długosz wspomniał, że wieś Dziesiąta graniczyła z Abramowicami (na tej granicy były usypane kopce graniczne) oraz z Wrotkowem, folwarkiem Bronowice i ze Świdnikiem (gdzie nie wyznaczono dokładnie granic): J. Długosz, Liber beneficiorum dioecesis Cracoviensis, wyd. A. Przeździecki, t. 1: Ecclesia cathedralis Cracoviensis - ecclesiae collegiatarum, Kraków 1863, s. 199.

5 H. Danczowska, Dziesiąta. Dzieje dzielnicy Lublina, Lublin 2007, s. 25; M. Markowski, Rozwój, s. 27.

6 Plany i widoki Lublina, Plansza XVI: Plan Wielkiego Miasta Lublina, Biuro Regulacji Magistratu m. [iasta] Lublina, 1931.

7 Plany i widoki Lublina, Plansza XVII: Plan M. [iasta] Lublina, 1938.

8 Plany i widoki Lublina, Plansza XIX: Verkhersplan Lublin [Plan komunikacyjny Lublina], Generalstab Des Heeres, około 1940 [dalej: Mapa 1940]. Mapa oparta 0 polską mapę WIG z 1937 r. (Pas 44, Słup 35)

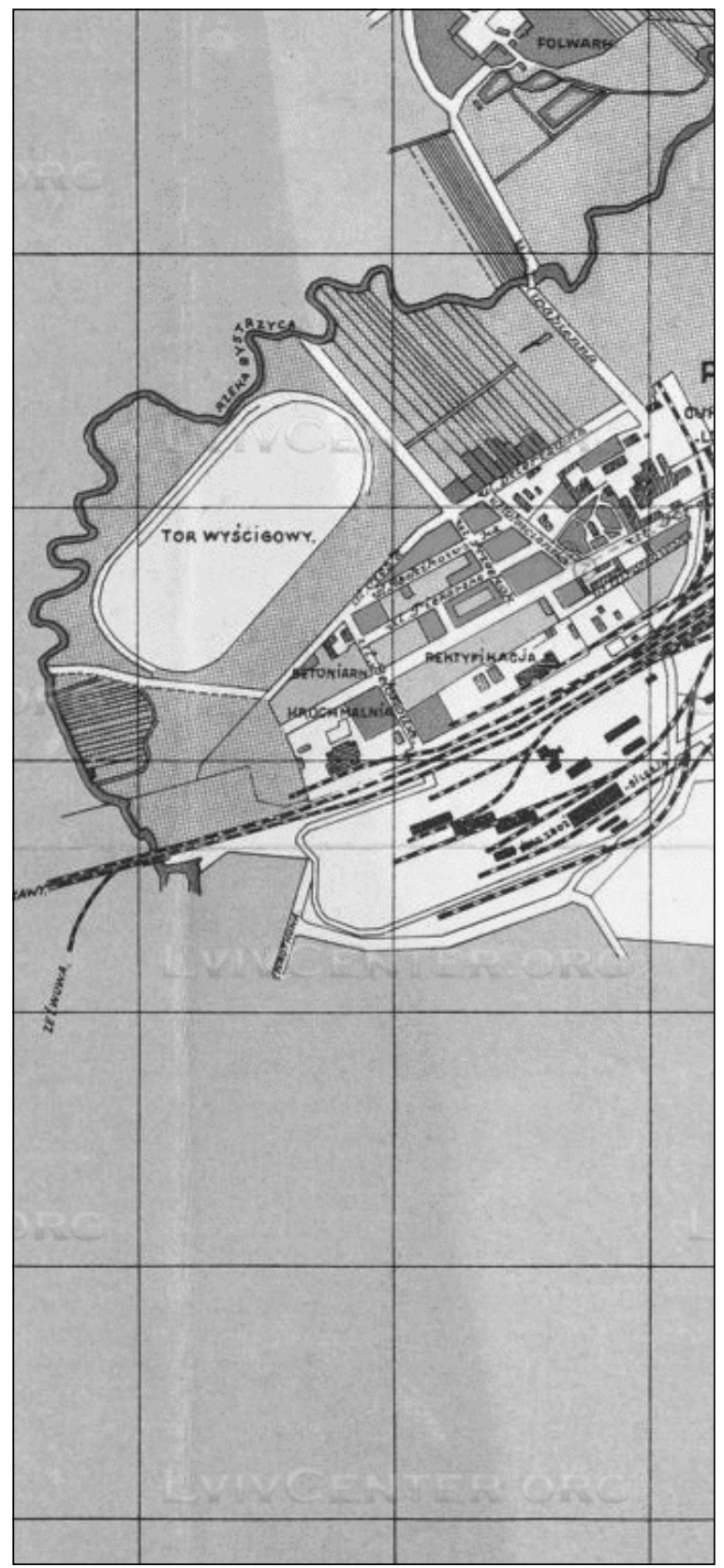

Ryc. 1. Fragment Planu wielkiego m. Lublina z 1931 r., skala: 1:15000

w skali 1:100 000 [dalej: Mapa 1937], na której widoczne są te same szczegóły. Usytuowanie zakładu rakarskiego wobec linii wyznaczonej przez przebieg ulicy Wilczej pozwala także skorygować starsze plany Lublina na tym odcinku i z większą pewnością przyjąć, że wskazują one na przebieg granicy miasta właśnie po tej linii. 
Trwałość dawnych elementów krajobrazu i sieci drożnej w ramach wspótczesnej przestrzeni miejskiej... Artykuty

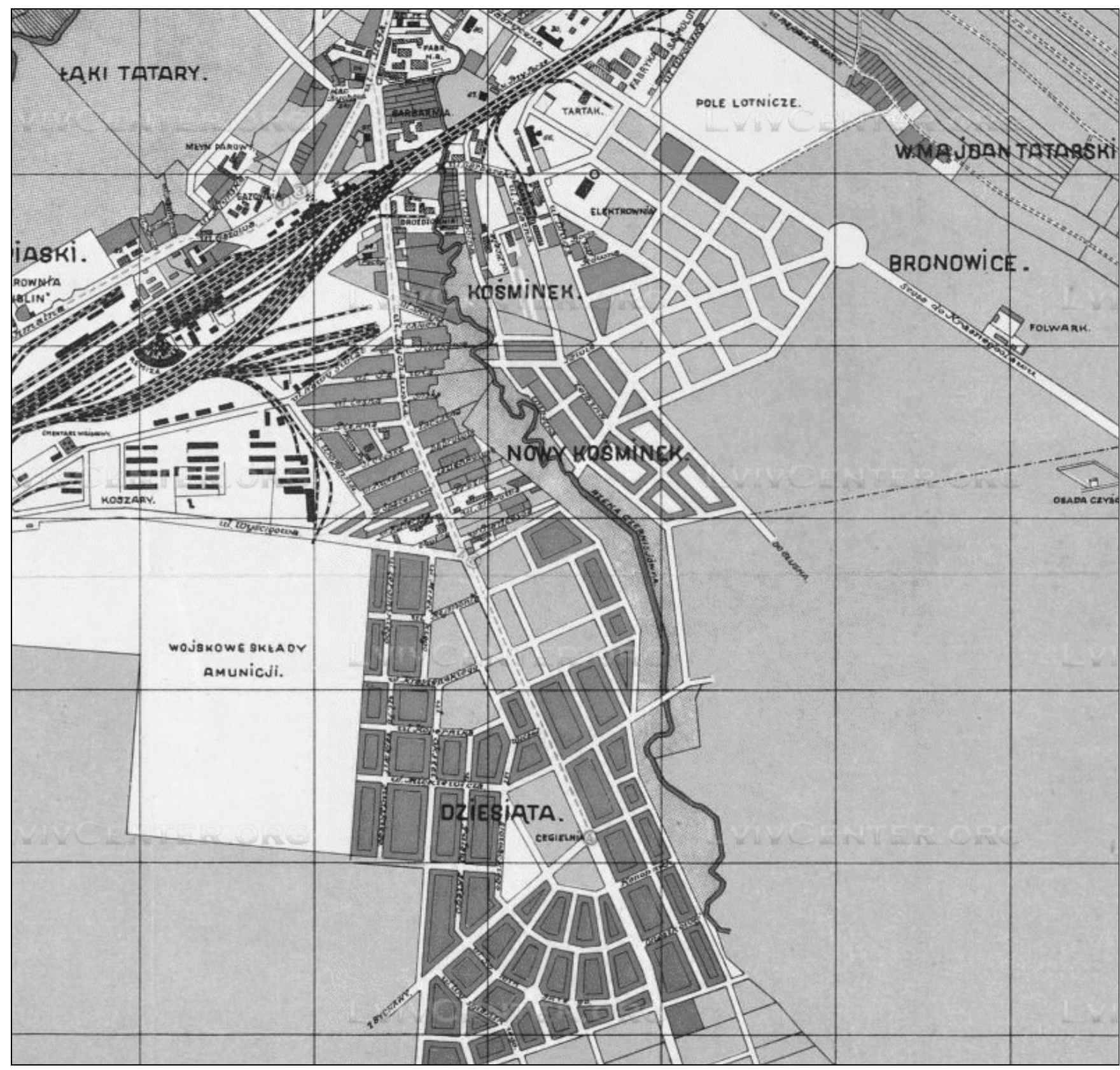

Źródto: Naukowa Biblioteka Lwowskiego Narodowego Uniwersytetu im. I. Franki we Lwowie, Dział Rękopisów, Starodruków i Rzadkich Ksiagg im. F. P. Maksymenki (Centrum historii miejskiej Europy Środkowo-Wschodniej, http://www./vivcenter.org/pl/umd/map/?ci_mapid=178\#tabGeneral, dostęp: 13.08.2014)

zało się z istnieniem lokalnego traktu, prowadzącego równolegle do pól tej wsi, być może w pobliżu granic z wsią Bronowice. Podobny wniosek można wysnuć także na podstawie analizy pla- nu Lublina z 1947 r. Przebieg ulicy Wilczej pokrywa się na nim z linią równoległą do granic działek na obszarze usytuowanym na północny wschód od terenu dawnego obozu koncen- 
tracyjnego na Majdanku9. Są to bez wątpienia granice pól należących w epoce nowożytnej do gruntów wsi Dziesiąta. Na żadnym z wymienionych planów nie znajdujemy jednak zaznaczonej ulicy Wilczej (poza krótkim odcinkiem w rejonie ulicy Długiej), ani nawet drogi biegnącej w miejscu, gdzie później (od 1947 r.) nanoszono ją na plany Lublina. Wiele wskazuje jednak na to, że droga taka istniała, a najlepszym dowodem na podparcie tej tezy jest plan sytuacyjny obozu koncentracyjnego na Majdanku (w którego obrębie znalazła się większa jej część). Plan wskazuje wyraźnie na istnienie drogi biegnącej od skrzyżowania z ulicą Długą, ukośnie w stosunku do osi szosy Lublin-Chełm (dzisiejsza Droga Męczenników Majdanka). Droga ta nie docierała do samej szosy, lecz kończyła się w przybliżeniu na wysokości innej wewnętrznej drogi (na linii dzisiejszej ulicy Kazimierza Przerwy-Tetmajera), biegnącej równolegle wobec szosy do Chełma ${ }^{10}$. Ponieważ trudno przypuszczać, by wspomniana droga została wytyczona dopiero po utworzeniu obozu (jej przebieg wydaje się nielogiczny, należałoby się spodziewać, że w przypadku jej celowego wyznaczenia przez Niemców byłaby lepiej połączona z innymi wewnętrznymi drogami na terenie obozu), sensownym wnioskiem wydaje się uznanie, że istniała ona wcześniej.

Skoro, jak już zaznaczyliśmy, nie znajdujemy potwierdzenia tego faktu na dwudziestowiecznych planach Lublina, należy sięgnąć do wcześniejszych materiałów kartograficznych. $\mathrm{Na}$ Topograficznej karcie Królestwa Polskiego ${ }^{11}$ z łatwością odnajdujemy rejon dzisiejszej ulicy Wilczej. Mapa ukazuje wąski, zapewne także posiadający stromeściany wąwóz, którego wylot na dolinę Czerniejówki można z dużym prawdopodobieństwem lokalizować w przybliżeniu w rejonie dzisiejszego zakończenia ulicy Wil-

\footnotetext{
9 Plany i widoki Lublina, Plansza XXI: Lublin, Biuro Pomiarów Zarządu Miejskiego w Lublinie, 1947. Wspomniany układ pól, będący bez wątpienia pozostałością podziałów pól wsi Dziesiąta jest łatwo czytelny do dnia dzisiejszego na zdjęciach satelitarnych na południe i południowy wschód od terenu dawnego obozu koncentracyjnego na Majdanku oraz usytuowanego na południowy wschód od niego cmentarza.

10 J. Marszałek, Majdanek. Obóz koncentracyjny w Lublinie, Warszawa 1981, Plan sytuacyjny obozu koncentracyjnego na Majdanku (między s. 8 i 9). Ulica Krańcowa stanowiła granicę terenu obozu od strony północno-zachodniej.
}

czej przy skrzyżowaniu z Robotniczą ${ }^{12}$. Wąwóz biegł od tego miejsca na północny wschód, by następnie przybrać kierunek niemal wschodni, a potem nawet południowo-wschodni i osiagał rejon szosy biegnącej w kierunku Piask (i dalej Chełma). Jego odgałęzienia wyraźnie przekraczały nawet tę szosę. Wątpliwości, czy opisany wąwóz można lokalizować w rejonie późniejszej ulicy Wilczej, rozwiewają przytaczane już mapy z 1937 i 1940 r. $^{13}$ Łatwe do odczytania poziomice, wyrysowane na tych mapach, pozwalają zlokalizować sam wąwóz (jego kształt jest bardzo bliski informacjom przekazanym przez Mapę Kwatermistrzostwa, choć jest znacznie szerszy i posiada znacznie łagodniejsze stoki) i dojść do przekonania, że ulica Wilcza pokrywała się z jego dolnym odcinkiem. W świetle informacji, jakie posiadamy z czasów istnienia obozu koncentracyjnego na Majdanku, możemy się spodziewać, że na przedłużeniu „urywającej się” na mapach z lat trzydziestych ulicy Wilczej istniała także jakaś droga biegnąca w kierunku północno-wschodnim.

Podłużne obniżenie terenu, widoczne na mapach $\mathrm{z}$ lat trzydziestych XX w. (zapewne tożsame z „wąwozem” z Mapy Kwatermistrzostwa), stosunkowo łatwo można odnaleźć także dzisiaj. Obejmuje ono dość spory obszar, w swej dolnej części (na wysokości biegnącej prostopadle wobec niego ulicy Długiej) ma ponad 400 metrów szerokości. Dla naszych rozważań istotny jest fakt, że ulice Krańcowa i Wilcza wyznaczają do pewnego stopnia rozmiary tego obniżenia. Obydwie ulice biegną bowiem równolegle wobec głównej jego części, przy czym Krańcowa jest ostatnią drogą przebiegającą przez płaskowyż położony na północny zachód od obniżenia, zaś Wilcza prowadzi wzdłuż południowo-zachodniej części

\footnotetext{
11 Topograficzna karta Królestwa Polskiego (tzw. Mapa Kwatermistrzostwa), kol. VI, sek. X.

12 Może na to wskazywać usytuowanie wylotu „wąwozu" wobec łatwiejszych do lokalizacji elementów topografii lewego brzegu Czerniejówki. Sam sposób przedstawienia ukształtowania terenu na mapie może wzbudzać problemy interpretacyjne. Jest to jednak zagadnienie znacznie wykraczające poza niniejsze rozważania i w dalszej częśc artykułu nazywając zaznaczone na Mapie Kwatermistrzostwa obniżenie terenu używamy określenia „wąwóz".

13 Mapa 1937; Mapa 1940.
} 
Trwałość dawnych elementów krajobrazu i sieci drożnej w ramach wspótczesnej przestrzeni miejskiej... Artykuty

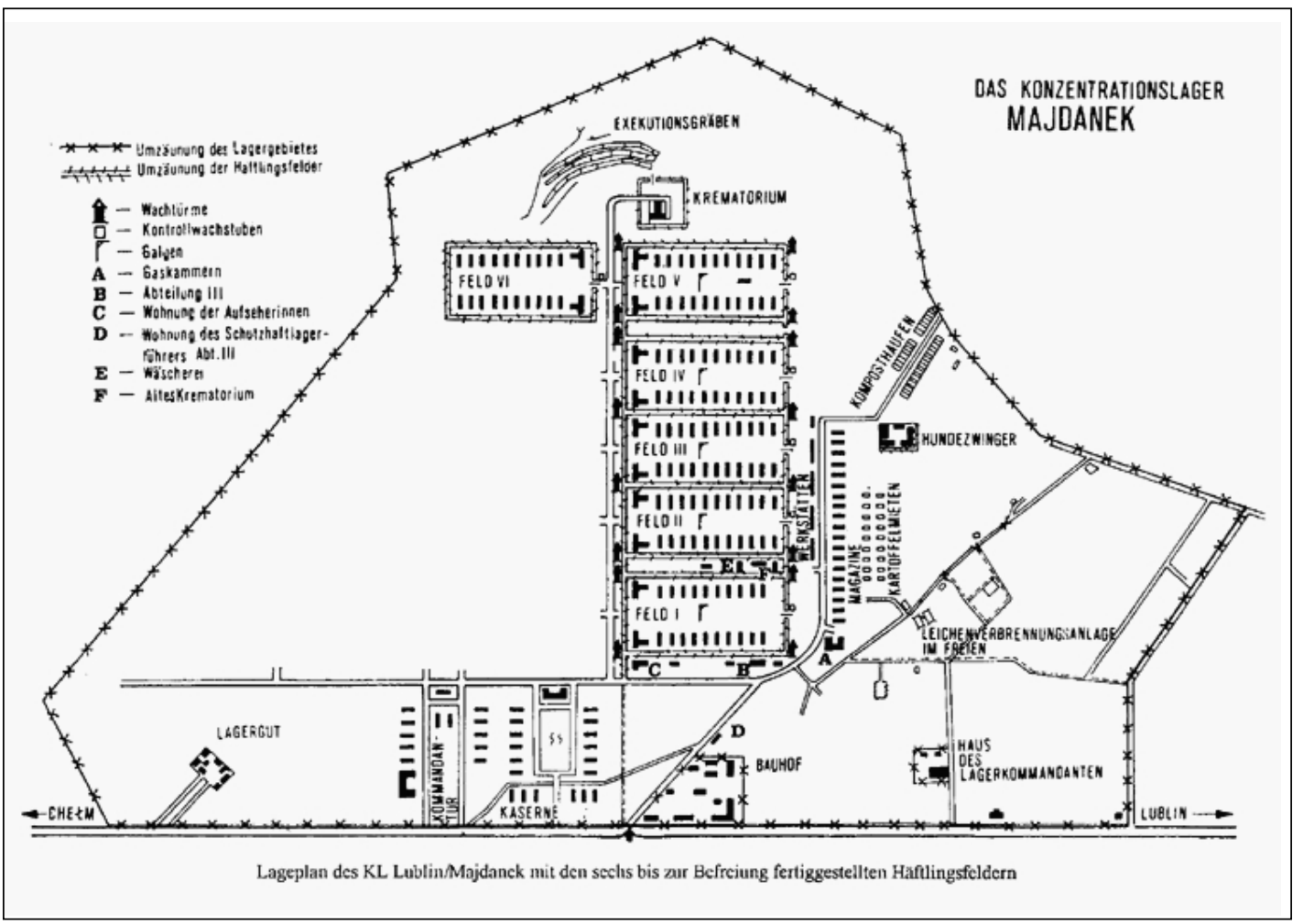

Ryc. 2. Plan sytuacyjny obozu koncentracyjnego na Majdanku z ok. 1940 r.

Żródto: J. Marszałek, Majdanek. Obóz koncentracyjny w Lublinie, Warszawa 1981, między s. 8 i 9

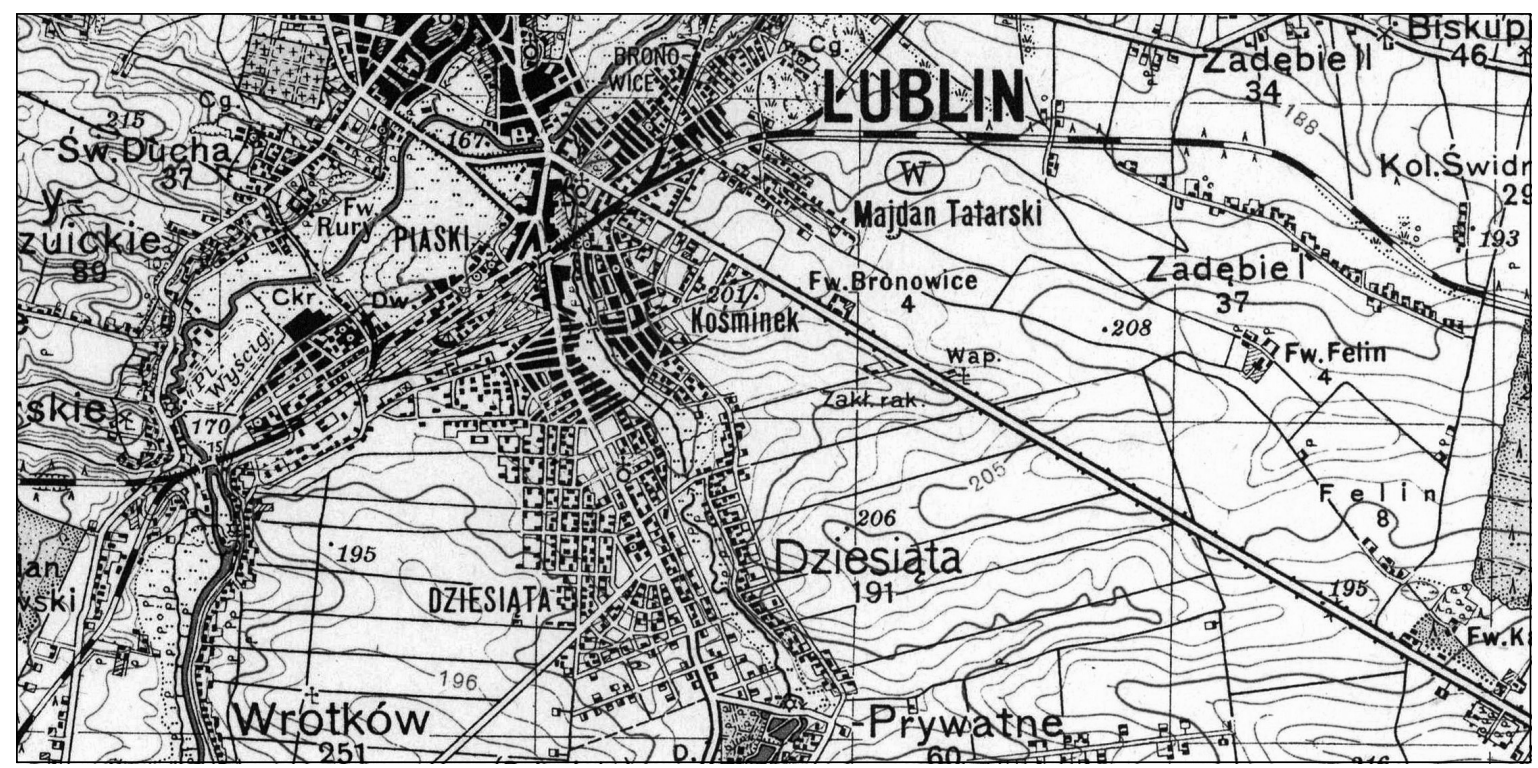

Ryc. 3. Fragment Lublina na mapie WIG z 1937 r., pas 44, stup 35, skala 1:100 000 
samego „wąwozu”. Teren bardzo wyraźnie obniża się na południowy wschód od ulicy Krańcowej, a zaczyna się podnosić dopiero za linią ulicy Wilczej. Ponieważ omawiany obszar jest dzisiaj objęty tylko zabudową jednorodzinną, „wąwóz" można stosunkowo łatwo odszukać w terenie, a na odcinku Długiej (między Krańcową a Wilcza) jest czytelny bez najmniejszego trudu. Obniżenie terenu jest widoczne także na wysokości Drogi Męczenników Majdanka, ale ze względu na kształt i kierunek „wąwozu”, odpowiadający obniżeniu terenu, spadek zaczyna się dopiero od wysokości ulicy Sulisławickiej i sięga do wysokości terenu dawnego obozu koncentracyjnego ${ }^{14}$. Dla naszych ulicę Wilczą od strony terenu dawnego obozu koncentracyjnego bardzo łatwo zauważymy, że stanowi ona niezbyt szeroki wąwóz, posiadający przedłużenie w postaci łagodniejszego obniżenia terenu biegnącego ukośnie przez teren obozu w kierunku Drogi Męczenników Majdanka.

Wydaje się zatem niemal pewnym, że opisane obniżenie terenu, w kształcie podłużnej doliny czy „wąwozu”, musiało istnieć dawniej. Zapewne także przebieg części ulic przecinających obecną Długą nie jest zaplanowany całkowicie przypadkowo, bez uwzględnienia istniejących wcześniej w tym rejonie dróg lokalnych. Podstawowe pytanie, na które powinniśmy podjąć

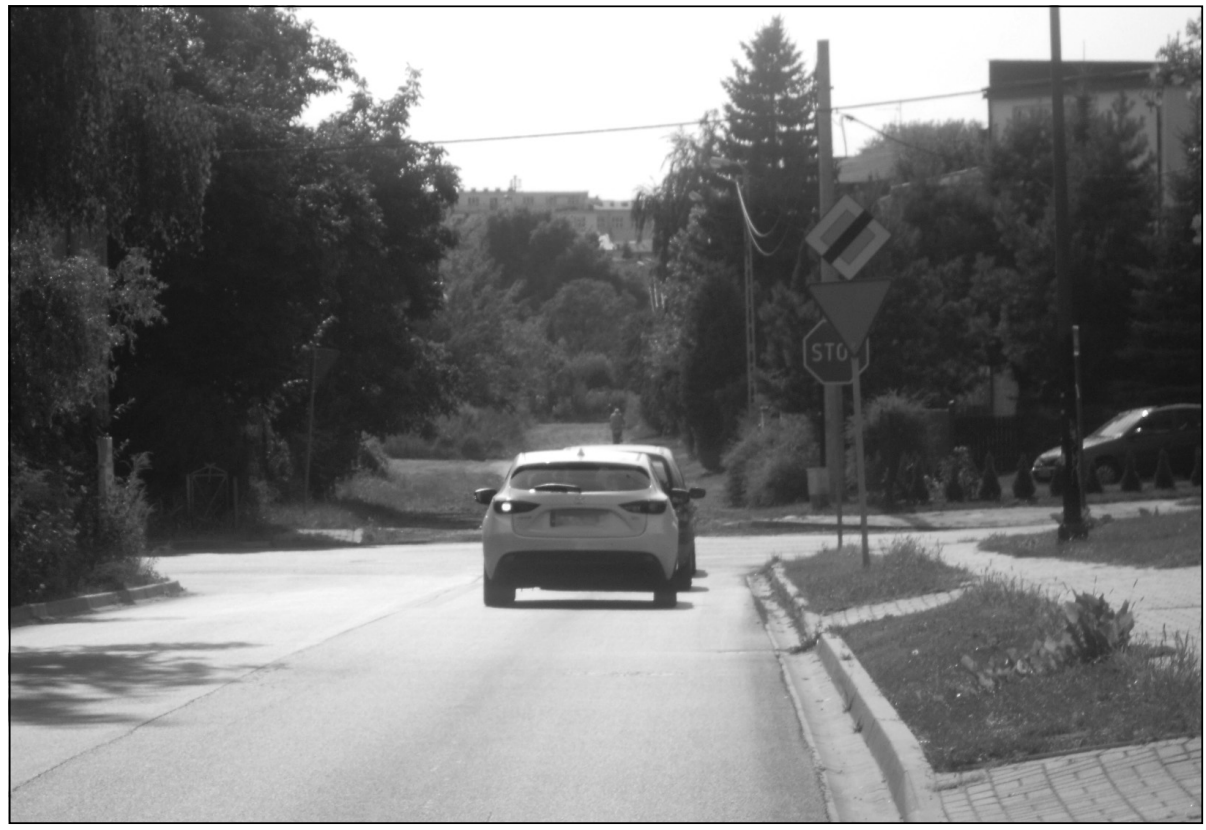

Fot. 1. Obniżenie terenu przy skrzyżowaniu ulic Długiej i Wilczej. Na horyzoncie, na linii osi ulicy Wilczej widoczny budynek Gimnazjum nr 1, przy skrzyżowaniu ulic Kunickiego i Wyścigowej. (fot. J. Chachaj)

rozważań istotny jest fakt, że najniższe miejsce opisywanego obniżenia terenu (które można nazwać „dnem wąwozu”) na wysokości ulicy Długiej pokrywa się z dolnym odcinkiem ulicy Wilczej, zaś na wysokości Drogi Męczenników Majdanka wypada na linii biegnącej krańcem terenu dawnego obozu, będącej przedłużeniem Wilczej. Zarazem obserwując próbę odpowiedzi, dotyczy kwestii, dlaczego na Mapie Kwatermistrzostwa narysowano nie dość szeroką dolinę, lecz wąski wąwóz posiadający

\footnotetext{
14 Od północnego zachodu można odnieść wrażenie, że obniżenie zaczyna się tuż za skrzyżowaniem z ulicą Krańcową. Zapewne jednak pewna kulminacja wysokości jezdni na tym odcinku Drogi Męczenników Majdanka jest sztucznego pochodzenia, o czym może świadczyć brak podobnej kulminacji na terenach przylegających z obu stron do jezdni.
} 
strome krawędzie boczne ${ }^{15}$. Być może powinniśmy się domyślać, że autorzy mapy zaznaczyli w ten sposób fakt, że wspomniana forma terenu mogła mieć w pewnych okolicznościach określone znaczenie wojskowe. Można przypuszczać, że w rzeczywistości dolina nie miała aż tak stromych bocznych ścian, by stać się przeszkodą komunikacyjną, bo na mapie przecinają ją biegnące wobec niej prostopadle drogi $^{16}$ (jedna łączy wieś Dziesiątą z Bronowicami, druga $-z$ Tatarami $\left.{ }^{17}\right)$. Skoro zatem wąwóz nie był przeszkodą (choć potencjalnie mógł zapewne stanowić linię obrony), jego znaczenia możemy doszukiwać się $\mathrm{w}$ innym czynniku. Czynnikiem tym mógł być fakt, że sam wąwóz był prawdopodobnie małą lokalną drogą, choć wydaje się, że znaczenie tej drogi w czasie powstawania mapy, a zatem po wytyczeniu w pierwszych dekadach XIX w. nowoczesnych traktów bitych, które zasadniczo zmieniły sieć drożną w okolicach Lublina, należało już raczej do przeszłości.

Dokładniejsza analiza treści mapy wskazuje jednak, że taka droga mogła wcześniej istnieć. Należy zauważyć, że trakt uściługski (dzisiejsze ulice Fabryczna i Droga Męczenników Majdanka oraz szosa w kierunku Piask będąca ich przedłużeniem), który zastąpił starą drogę wiodącą z Lublina do Piask, biegnącą nieco dalej na północ (przez Tatary, Zadębie, Krępiec i Wierzchowiska), został wyznaczony w ten sposób, że od znajdujących się na wschodnich krańcach Lublina rogatek piaseckich biegł po idealne prostej linii niemal do samych Piask. Po drodze przecinał większy obszar lasów, których niewielką pozostałością jest las Krępiec między Lublinem a Świdnikiem, a także lasy na pół-

\footnotetext{
15 Wąwóz ten zapewne odpowiadał przebiegowi dna opisanego wyżej obniżenia terenu.

16 W tej sprawie istotne mogą być uwagi podnoszone w przypisie 12.

17 Pochodzący z 1530 r. opis granicy między wsiami Tatary i Bronowice wspomina 0 drodze biegnącej od wsi Dziesiąta i Bronowice do Lublina: J. Riabinin, Materiały do historii miasta Lublina, Lublin 1938, nr 125, s. 44. Nie mogła to być jednak żadna z dróg zaznaczonych na Mapie Kwatermistrzostwa, a zapewne raczej jakiś odcinek traktu biegnącego w kierunku Tatar (i znajdującej się na północ od wsi przeprawy na drodze do Lublina). Dodatkowo można przypuszczać, że wspomniana w opisie z XVI w. droga znajdowała się stosunkowo blisko Tatar. Skoro bowiem tekst nie wspomina 0 dwóch drogach
}

noc od Świdnika, las między Kazimierzówką a Bystrzejowicami i inne podobnych rozmiarów lasy dalej na południe. W pierwszej połowie XIX w., a zapewne także wcześniej, wspomniany kompleks leśny wyznaczał ukształtowaną jeszcze we wczesnym średniowieczu granicę osadnictwa między dawną parafią lubelską a mełgiewską ${ }^{18}$. Na Mapie Kwatermistrzostwa, na wschodnim skraju wspomnianego lasu znajduje się przy trakcie uściługskim karczma Kaleń (znajdująca się na terenie dzisiejszej Kalinówki) ${ }^{19}$. Nie może być przypadkiem, że miejsce to jest lokalnym węzłem drogowym, bo poza traktem biegnącym stąd wprost do Lublina, zaznaczono także wychodzące z okolic karczmy dwie inne drogi. Jedna z nich prowadziła w kierunku bardzo starej przeprawy przez Bystrzycę na północ od Tatar (gdzie zaznaczono karczmę Budzyń), inna - do leżącej nad Czerniejówką wsi Abramowice (zapewne równolegle do granic pól w tym rejonie). Wiele wskazuje na to, że karczma istniała już w epoce nowożytnej, stanowiąc miejsce postoju przed odcinkiem drogi prowadzącej przez większy kompleks leśny. Dlatego właśnie zbiegały się w jej rejonie drogi o różnym znaczeniu, biegnące z zachodu.

Wszystko to prowadzi do postawienia hipotezy, że opisany przez nas wyżej „wąwóz” był wcześniej lokalną drogą, która mogła być jednym z traktów biegnących na zachód od karczmy Kaleń. Kształt „wąwozu” zaznaczony na mapie pozwala przyjąć dwie możliwości wschodniego przebiegu tego traktu. Mógł on biec zarówno w przybliżeniu trasą wyznaczonej w pierwszych dekadach XIX w. szosy uściługskiej, jak też oddzielać się na którymś odcinku od drogi bie-

(osobnej z Bronowic i osobnej z Dziesiątej), to można sądzić, że łączyły się one w jeden trakt przed wsią Tatary.

18 Województwo lubelskie w drugiej połowie XVI wieku, red. W. Pałucki, oprac. S. Wojciechowski, Warszawa 1966 (Atlas historyczny Polski. Mapy szczegótowe XVI wieku, 3).

19 Miejsce (vadum, czyli przeprawę?) zwane Kaleń, gdzie stykają się grunty świdnickie i krempieckie, i gdzie znajduje się granica wsi Tatary, wspomina Lustracja z 1602 r.: J. Riabinin, Materiaty do historii, nr 267, s. 89. W innym miejscu Lustracja mówiła 0 „uroczysku Kaleń", gdzie stykają się granice świdnicka i tatarska (tamże, s. 91), a wydaje się, że także wzmianka 0 „klinie Uroczysku tak zwanym” (s. 90) dotyczy Kaleni. 
gnącej z karczmy Kaleń w kierunku przeprawy przez Bystrzycę, na zachód od karczmy Budzyń. Niezależnie jednak od tego, którym wariantem poprowadzilibyśmy tę hipotetyczną drogę na jej wschodnim odcinku, należy odpowiedzieć także na pytanie, dokąd prowadziła. Dwie istniejące bez wątpienia inne drogi pozwalały na łatwą komunikację rejonu karczmy Kaleń zarówno z Lublinem, jak też osadami leżącymi na południe od miasta (bezpośrednio z Abramowicami, a stamtąa pośrednio zarówno z Dziesiątą, jak też Głuskiem i wsiami leżącymi dalej na południe wzdłuż Czerniejówki). Może jednak zwracać uwagę fakt, że brakowało bezpośredniego połączenia z Wrotkowem, a co za tym idzie musiały występować komplikacje dla osób zmierzających w kierunku zachodnim, na przykład do Konopnicy (będącej już od średniowiecza siedzibą parafii). Najprostszym połączeniem rejonu karczmy Kaleń z Konopnicą wydaje się w takiej sytuacji podróż przez Abramowice, przeprawa przez Czerniejówkę w Abramowicach lub Głusku, następnie podróż do przeprawy przez Bystrzycę między Wrotkowem a Zemborzycami, a w końcu pokonanie okrężnej trasy wokół lasu, zwanego dzisiaj Starym Gajem. Cała podróż wydaje się dość skomplikowana, a jej alternatywą była droga prowadząca przez Lublin.

Przyjęcie hipotezy o istnieniu dawnej drogi biegnącej „wąwozem” w okolicy późniejszej ulicy Wilczej rozwiązuje ten problem. Jeśli droga ta istniała, prowadziłaby ku Czerniejówce, gdzie powinniśmy założyć istnienie nieznanej nam przeprawy przez bagnistą dolinę rzecznąa (podobna przeprawa musiała istnieć nieco dalej

200 bagnie, przez które płynie rzeka od Dziesiątej w kierunku Bronowic (czyli Czerniejówka) informuje zapis z 1511 r.: J. Riabinin, Materiały do historii, nr 107, s. 35.

21 Kontynuacją tego traktu jest ulica Bychawska (dziś Władysława Kunickiego).

22 Początek tej drogi znajdował się w okolicy dzisiejszego skrzyżowania ulic Władysława Kunickiego i Wyścigowej. Rejon jest wyraźnie widoczny, gdy patrzy się wzdłuż osi ulicy Wilczej.

23 Zabagniona dolina Bystrzycy stanowiła bardzo poważną przeszkodę komunikacyjną. Problem z jej przekroczeniem pojawił się także w latach siedemdziesiątych XIX w., gdy budowano linię kolejową łączącą Warszawę z Kowlem przez Lublin. Dolina Bystrzycy była na tyle szeroka, że rozważano tylko dwie możliwości budowy mostu kolejowego przez rzekę. Jeden wariant zakładał budowę mostu kolejowego w rejonie starej przeprawy na Kalinowszczyźnie, drugi - koło przeprawy w górę rzeki zapewniając komunikację między położoną na prawym, wschodnim brzegu wsią Dziesiąta, a leżącym na lewym, zachodnim brzegu folwarkiem; istnienie takiej przeprawy sugeruje zresztą Mapa Kwatermistrzostwa). Gdyby przeprawa istniała także na przedłużeniu dolnej partii „wąwozu” (czyli dzisiejszej ulicy Wilczej), hipotetyczna droga łączyłaby się na lewym brzegu ze starym traktem biegnącym równolegle wzdłuż Czerniejówki w kierunku lubelskiego przedmieścia Piaski ${ }^{21}$. Zwraca jednak uwagę fakt, że właśnie w tym miejscu odchodziła od traktu wyraźnie widoczna na Mapie Kwatermistrzostwa droga skierowana niemal dokładnie na zachód ${ }^{22}$, która prowadziła aż do północnych krańców wsi Wrotków i łączyła się ze znajdującym się w tym terenie węzłem drogowym, powiązanym $\mathrm{z}$ wygodną przeprawą doliną Bystrzycy ${ }^{23}$. Wschodni odcinek tej drogi jest czytelny do dzisiaj w postaci ulicy Wyścigowej, zachodni zatarł się w drugiej połowie XIX i w pierwszych dekadach XX w. w toku zmian organizacji terenu po wytyczeniu linii kolejowej ${ }^{24}$.

Jak się zatem wydaje można postawić hipotezę, że istniała kiedyś droga, której pozostałością jest południowo-zachodni odcinek ulicy Wilczej. Łączyła ona okolice karczmy Kaleń przez nieznaną nam przeprawę na Czerniejówce, z drogą biegnącą ku przeprawie na Bystrzycy na północ od Wrotkowa. Byłaby to najkrótsza droga łącząca rejony położone na zachód i południowy zachód od Lublina, leżące na zachodnim brzegu Bystrzycy, z okolicami karczmy Kaleń, która, jak wskazaliśmy wyżej,

na Wrotkowie. Wybrano ten drugi wariant, który uchodził za bardziej racjonalny, co ma szczególne znaczenie dla naszych rozważań Por.: A. Kierek, Rozwój przestrzenny i stan urządzeń komunalnych m. Lublina w latach 1870-1915, „Rocznik Lubelski”, 4, 1961 , s. 174-176; tenże, Rozwój Lublina w latach 1864-1914, w: Dzieje Lublina. Próba syntezy, t. 1, Lublin 1965, s. 257.

${ }^{24}$ W początkach XX w. tereny na północ od ulicy Wyścigowej znajdujące się wzdłuż traktu do Bychawy zostały objęte zabudową przemysłową i stały się jednym z robotniczych przedmieść Lublina, włączonych do miasta w 1916 r. Na obszarze znajdującym się na zachód od tego przedmieścia powstały koszary, nazywane Obozem Południowym. W późniejszym czasie teren wojskowy powiększył się w kierunku południowym, obejmując także widoczny na Mapie Kwatermistrzostwa las oraz grunty wsi Wrotków. Część tego obszaru należy do wojska do dnia dzisiejszego. 
była istotnym punktem na szlaku wiodącym z Lublina w kierunku południowo-wschodnim. Jak się wydaje, opisana droga w XIX w. już nie funkcjonowała jako trakt o przynajmniej lokalnym znaczeniu, choć nie można wykluczyć, że pozostawała szlakiem komunikacji najniższego szczebla (na przykład jedną z dróg łączących sąsiednie wsie). Utratę znaczenia opisanego przez nas szlaku, a konsekwencji jego zanik, można zapewne łączyć z powstaniem, prawdopodobnie w pierwszej połowie XVIII w., nowej przeprawy na Bystrzycy w okolicach istniejącego dzisiaj mostu na przedłużeniu ulicy Zamojskiej ${ }^{25}$. Powstanie tej nowej przeprawy, która połączyła Żmigród z terenami leżącymi na prawym, południowym brzegu Bystrzycy, doprowadziło do istotnych zmian sieci drożnej oraz sytuacji osadniczej w najbliższej okolicy. Skutkiem jej powstania był zapewne szybki rozwój przedmieścia nazywanego Nowym Kazimierzem, na związanym z Bronowicami gruncie nazywanym Piasek, a później Piaski ${ }^{26}$. $\mathrm{Z}$ wytyczeniem nowej przeprawy na Bystrzycy wzrosło także znaczenie istniejącej już wcześniej przeprawy przez Czerniejówkę w okolicach ujścia tej rzeki do Bystrzycy ${ }^{27}$, a w konsekwencji także łączącej Tatary z Wrotkowem drogi biegnącej równolegle do Bystrzycy jej prawym, południowo-wschodnim brzegiem (pokrywającej się w przybliżeniu z dzisiejszymi ulicami Łęczyńską i Krochmalna). Bez wątpienia także wtedy musiały ostatecznie nabrać większego znaczenia północne odcinki dróg biegnących wschodnim skrajem płaskowyżu położonego w widłach Bystrzycy i Czerniejówki, równolegle wobec zachodniego brzegu doliny tej ostatniej rzeki (dzisiejsza ulica W. Kunickiego) oraz zachodnim skrajem płaskowyżu rozciągającego

\footnotetext{
25 Istnienie przeprawy przez Bystrzycę w rejonie usytuowanym na południe od Żmigrodu ukazuje plan Lublina z 1716 r.: Plany i widoki Lublina, Plansza II: Plan de la ville et fauxbourgs de Lublin [Plan miasta i przedmieść Lublina], C. V. d'Örken, 1716. Stanowi to dla części badaczy przesłankę do uznania, że przeprawa ta mogła powstać nawet wcześniej. Zarazem uznaje się, że istniała ona w przybliżeniu tu, gdzie później zbudowano most i usytuowano rogatkę piasecką, czyli na linii dzisiejszej ulicy Zamojskiej. Tymczasem dokładniejsza analiza planu z 1716 r. wskazuje, że zarówno przedstawiona na nim droga skierowana na południe ze Żmigrodu, jak i sama przeprawa powinny być lokalizowane raczej nieco dalej na zachód, na linii ulicy
}

się na północny wschód od Czerniejówki (dzisiejsza ulica Długa). Były to bowiem najkrótsze drogi łączące nową przeprawę przez Bystrzycę (a zatem i Lublin) z rejonem starego, bez wątpienia średniowiecznego osadnictwa na obu brzegach Czerniejówki.

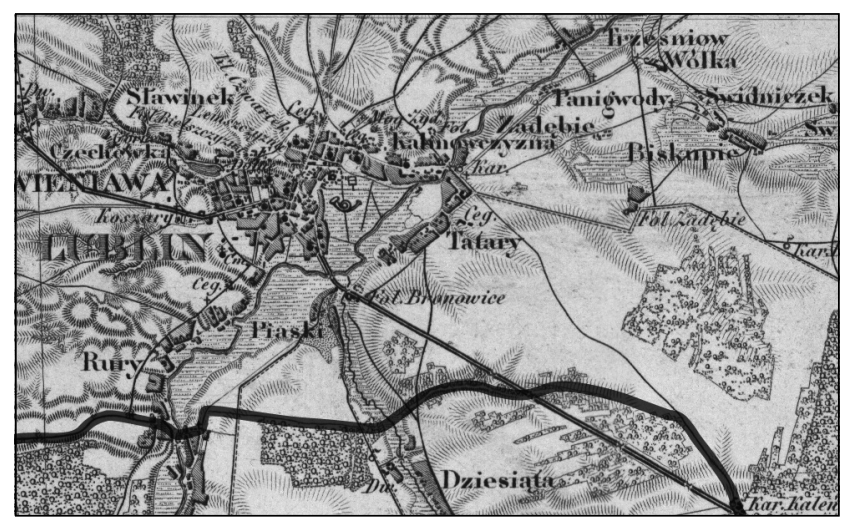

Ryc. 4. Rekonstrukcja przebiegu potencjalnego traktu komunikacyjnego na tle Mapy Kwatermistrzostwa

Można się zatem spodziewać, że właśnie w pierwszej połowie XVIII opisana przez nas droga stałą się mniej uczęszczana, co doprowadziło, być może po jednej z częstych zapewne powodzi, do zaniku przeprawy przez dolinę Czerniejówki na przedłużeniu dzisiejszej ulicy Wilczej. Wniosek ten prowadzi zarazem do postawienia hipotezy łączącej powstanie tej drogi z okresem jeszcze wcześniejszym. Jej przebieg stokiem obniżenia terenu pozwala przypuszczać, że mogła się ona wytworzyć w naturalny sposób w stosunkowo zamierzchłej przeszłości, zapewne jeszcze w średniowieczu. Być może zatem istniejący dziś południowo-zachodni odcinek ulicy Wilczej jest reliktem bardzo

Wesołej. W efekcie nie da się zapewne cofnąć powstania przeprawy na wysokości ulicy Zamojskiej na okres poprzedzający $1716 \mathrm{r}$.

26 J. Mazurkiewicz, Jurydyki lubelskie, Wrocław 1956, s. 40; M. Buczyński, Nazwy dzielnic i przedmieść Lublina, „Rocznik Lubelski”, 5, 1962, s. 255; Dzieje Lubelszczyzny, t. 4: Osady zaginione i 0 zmienionych nazwach historycznego województwa lubelskiego, oprac. S. Wojciechowski, A. Sochacka, R. Szczygieł, Warszawa 1986, s. 103-104.

27 Przeprawa, zapewne o znaczeniu lokalnym, musiała istnieć wcześniej, skoro Piaski zaliczano do gruntów folwarku Bronowice, położonego na prawym, wschodnim brzegu Czerniejówki. 
starego traktu, który przetrwał, mimo bardzo istotnych zmian organizacji przestrzeni w jego najbliższej okolicy. Z kolei część ulicy Krańcowej (od Kunickiego aż do końca prostego odcinka biegnącego w górę od ulicy Długiej w kierunku Drogi Męczenników Majdanka) wydaje się pozostałością dawnej granicy Lublina, a wcześniej być może pól folwarku bronowickiego. Pytaniem otwartym pozostaje kwestia

\section{Literatura}

\section{Źródła pisane}

J. Długosz, Liber beneficiorum dioecesis Cracoviensis, wyd. A. Przeździecki, t. 1: Ecclesia cathedralis Cracoviensis - ecclesiae collegiatarum, Kraków 1863.

\section{Źródła kartograficzne}

Mapa WIG, 1937, skala 1:100 000, Pas 44, Słup 35.

Plany i widoki Lublina XVII-XXI wiek, red. M. Harasimiuk, D. Kociuba, P. Dymmel, Lublin 2007, Plansza II: Plan de la ville et fauxbourgs de Lublin [Plan miasta $i$ przedmieść Lublina], C. V. d'Örken, 1716; Plansza XII: Plan prigrodskich miestnostiej priedlagajemych $k$ prisojdnieniu $k$ gorodu Liublinu, M. Stelmasiewicz, K. Tomorowicz, 19121914; Plansza XIII: Plan M.[iasta] Lublina. 1916; Plansza XV: Plan Lublina, A. Z. Krzy-

\section{Literatura przedmiotu}

Buczyński M., Nazwy dzielnic i przedmieść Lublina, „Rocznik Lubelski”, 5, 1962, s. 251-268.

Danczowska H., Dziesiata. Dzieje dzielnicy Lublina, Lublin 2007.

Dzieje Lubelszczyzny, t. 4: Osady zaginione i o zmienionych nazwach historycznego województwa lubelskiego, oprac. S. Wojciechowski, A. Sochacka, R. Szczygieł, Warszawa 1986.

Kierek A., Rozwój Lublina w latach 18641914, w: Dzieje Lublina. Próba syntezy, t. 1, Lublin 1965, s. 257-300. czy także tą granicą biegł w dawnych czasach jakiś lokalny trakt, ale wydaje się dość prawdopodobnym, że przebieg tej granicy, przede wszystkim na odcinku leżącym na północny wschód od ulicy Długiej nie jest przypadkowy. Można się domyślać, że jego wytyczenie związane było z istnieniem widocznego do dziś obniżenia terenu, którego skrajem biegła droga poprzedzająca ulicę Wilczą.

J. Riabinin, Materiaty do historii miasta Lublina, Lublin 1938.

żewski, 1926; Plansza XVI: Plan Wielkiego Miasta Lublina, Biuro Regulacji Magistratu m.[iasta] Lublina, 1931; Plansza XVII: Plan M. [iasta] Lublina, 1938; Plansza XIX: Verkhersplan Lublin [Plan komunikacyjny Lublina], Generalstab Des Heeres, około 1940; Plansza XXI: Lublin, Biuro Pomiarów Zarządu Miejskiego w Lublinie, 1947.

Topograficzna karta Królestwa Polskiego (tzw. Mapa Kwatermistrzostwa), 1822-1843, skala:1:126 000, kol. VI, sek. X.

Kierek A., Rozwój przestrzenny i stan urzadzeń komunalnych $m$. Lublina $w$ latach 1870-1915, „Rocznik Lubelski”, 4, 1961, s. $171-214$.

Markowski M., Rozwój przestrzenny Lublina w XX wieku, ,Rocznik Lubelski”, 38, 2012, s. 24-34.

Mazurkiewicz J., Jurydyki lubelskie, Wrocław 1956.

Województwo lubelskie $w$ drugiej potowie XVI wieku, red. W. Pałucki, oprac. S. Wojciechowski, Warszawa 1966 (Atlas historyczny Polski. Mapy szczegółowe XVI wieku, 3). 


\section{The durability of older elements of the landscape and the street network within the present-day urban area based on the examples of Krańcowa Street and Wilcza Street in Lublin}

\section{Summary}

The article attempts to demonstrate, basing on the example of Wilcza Street running through the south-eastern area of Lublin, that certain elements of the cultural landscape (primarily roads) could be preserved after the inclusion of suburban regions into the dynamically developing cities in the $19^{\text {th }}$ and $20^{\text {th }}$ centuries. Examination of the cartographic source material and the observation of the present-day landform have led to a hypothesis that the modern Wilcza Street could be a fragment of an old local road, which had lost its original

significance as a result of changes made to the street network, yet endured as a local road. For reasons unknown, it was integrated into and ran through the system of streets newly laid out in Lublin, allowing it to survive to this day. Despite the disappearance of most elements formerly associated with this road (crossings, the majority of other roads), the street survived the numerous changes in its surroundings and remains an example of the incredible durability of certain aspects of the cultural landscape.

Słowa kluczowe: ulica Wilcza w Lublinie, ulica Krańcowa w Lublinie, sieć drożna, rozwój przestrzenny miasta

Keywords: Wilcza Street in Lublin, Krańcowa Street in Lublin, street network, spatial planning of the city

dr hab. Jacek Chachaj - adiunkt w Katedrze Historii i Historiografii Europy Wschodniej

w Instytucie Historii KUL

(e-mail: chachaj@kul.lublin.pl) 